\title{
Assessment of weight gain and control of parasitism by Rhipicephalus microplus in dairy cattle in the field using organosynthetic parasiticide, phytotherapics and homeopathy
}

\author{
[Avaliação do ganho de peso e controle do parasitismo por Rhipicephalus microplus em bovinos \\ leiteiros a campo usando parasiticida organosintético, fitoterápicos e homeopatia]

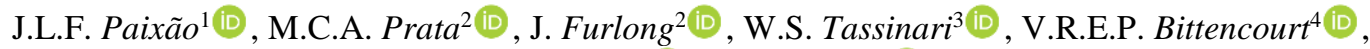 M.F.A. Pires ${ }^{2}$ (D) I.C. Angelo ${ }^{*}$ (D)
${ }^{1}$ Graduate, Universidade Federal Rural do Rio de Janeiro, Instituto de Veterinária, Seropédica, RJ, Brasil ${ }^{2}$ Embrapa Gado de Leite, Juiz de Fora, MG, Brasil
${ }^{3}$ Universidade Federal Rural do Rio de Janeiro, Instituto de Ciências Exatas, Seropédica, RJ, Brasil ${ }^{4}$ Universidade Federal Rural do Rio de Janeiro, Instituto de Veterinária, Seropédica, RJ, Brasil

\begin{abstract}
The goal of this research was to compare the effect of the following products on dairy cattle, parasitized by Rhipicephalus microplus: organosynthetics - Clorfenvinfós and Ivermectina (OG); phytotherapics Eucalyptus oil (EG) and Neem cake (NG); Homeopathy (HG); The control group (CG) received no treatment. Infestation was by $R$. microplus (MIC) and weight gain (GP) were evaluated. The study included 60 animals ( 5 groups) from $3 / 4$ Dutch / Zebu, aged between 25-44 months and initial weight between 211$477 \mathrm{~kg}$. EG and NG showed MIC $84.9 \%$ and $14.0 \%$ greater than CG, respectively $(\mathrm{P}<0.05 ; \mathrm{P}=0)$. HG and OG had MIC less than CG $24.4 \%$ and $16.9 \%$, respectively $(\mathrm{P}<0.05 ; \mathrm{P}<0.05)$. EG, NG and OG obtained GP lower than CG in 7.9\%, 8.9\% and $8.06 \%$ ( $\mathrm{P}<0.05)$ respectively. The HG GP was $4.9 \%$ higher $(\mathrm{P}<0.05)$ than CG. This was the first research to prove parasitism control by $R$. microplus in a field test, using homeopathy. The methodology for choosing Homeopathy for the control of enzooties, developed and tested for the first time in this study, proved to be adequate and efficient, opening the possibility for establishing a new methodology for strategic control of parasitism by $R$. microplus.
\end{abstract}

Keywords: ticks, organic milk, tick insecticide, alternative control, homeopathic remedy

\section{RESUMO}

O objetivo desta pesquisa foi comparar o efeito dos seguintes produtos sobre bovinos leiteiros, parasitados por Rhipicephalus microplus: organossintéticos - clorfenvinfós e ivermectina $(O G)$; fitoterápicos - óleo de eucalipto (EG) e torta de Neem (NG) e homeopatia (HG). O grupo controle (CG) não recebeu tratamento. Foram avaliados infestação por R. microplus (MIC) e ganho de peso/grupo (GP) em 60 animais (5 grupos), a partir de 3/4 holandês/zebu, com idade entre 25 e 44 meses e peso inicial entre 211 e $477 \mathrm{~kg}$. EG e NG apresentaram MIC $84,9 \%$ e $14,0 \%$ maior que $C G$, respectivamente $(P<0,05 ; P=0)$. HG e OG apresentaram MIC menor que CG 24,4\% e 16,9\%, respectivamente $(P<0,05 ; P<0,05)$. EG, NG e OG obtiveram GP menor que CG em 7,9\%, 8,9\% e 8,06\% (P<0,05), respectivamente. O GP do HG foi 4,9\% maior $(P<0,05)$ que o CG. Esta foi a primeira pesquisa a comprovar controle do parasitismo por $\mathrm{R}$. microplus em teste a campo, usando homeopatia. A metodologia para escolha de medicamentos homeopáticos para controle de enzootias, desenvolvida e testada pela primeira vez neste estudo, mostrouse adequada e eficiente, abrindo a possibilidade para estabelecimento de nova metodologia para controle estratégico do parasitismo por R. microplus.

Palavras-chave: carrapato, leite orgânico, carrapaticidas, controle alternativo, medicamento homeopático

\section{INTRODUÇÃ̃}

The tick Rhipicephalus microplus (Canestrini, 1888 ) is present in all Brazilian territory, as it is an important transmitter of pathogens (Dantas Torres et al., 2019; Figueiredo et al., 2018; Silveira et al., 2014) and responsible for causing major losses to livestock. In Brazil, these losses

*Corresponding author: isabeleangelo@yahoo.com.br Submitted: March 11, 2021. Accepted: June 11, 2021. 
were estimated at $\$ 3.24$ billion annually (Grisi et al., 2014). The main form of control is via organosynthetic parasiticides, but the inappropriate use has promoted the selection of resistant populations, leading to the use of larger and more concentrated doses, increasing the risk of contamination and the cost of production (Furlong and Sales, 2007; Rodriguez -Vivas et al., 2018).

There is an urgent need to develop or validate technologies that delay resistance and reduce costs and contamination, such as the use of resistant animals, herbal medicines, homeopathy, biological control, vaccines and the strategic control of bovine ticks (Nagar et al., 2018; Rodriguez-Vivas et al., 2018).

There is an increasing demand for scientific research that tests the comparative efficiency of different parasite control alternatives. This demand is pressured, mainly, by the growing importance of Organic Agriculture in the national and international market, driven by a consumer market that demands quality products, at a fair price, healthy from the point of view of food and nutritional security, free of biological residues and chemicals and produced with less use of artificial inputs, in addition to animal welfare care (Gazolla and Lovatel, 2020).

The selection of resistant breeds and the development of vaccines has been researched; however, they involve slow and expensive processes. In addition to the difficulty of selecting, at the same time, characteristics for increasing resistance and increasing production / productivity, the efficiency of vaccines available on the market is still not sufficient for the adequate control of the tick. Simultaneous tests of the strategic control already recommended, with homeopathic and phytotherapic preparations proven to be effective may have more immediate application, including for use in organic milk production (Almeida, 2013).

The results presented, mainly in vitro studies, may justify the enthusiasm of some authors in relation to the parasiticide potential of herbal medicines, because besides being allowed in organic production systems (Almeida, 2013; Pavela et al., 2016), they present faster degradation and leave no residue (Charlie-Silva et al., 2018). Azadirachta indica (Neem) is one of the most studied plants for the control of $R$. microplus. It has an insecticidal, repellent, antifungal and antibacterial action. It is promising as a broad spectrum parasiticide. Extracts from its seeds and its emulsifiable oil can kill $R$. microplus in a few days and negatively interfere with its reproduction (Catto et al., 2013; Costa et al., 2008; Valente et al., 2007).

Essential oils have great potential in the control of R. microplus (Pazinato et al., 2016). In this sense, phytotherapics from Eucalyptus plants have also been studied as ticks (Galli et al., 2018). The species Eucalyptus citriodora and Eucalyptus globulus are the most studied, both with antiparasitic action proven in vitro (Campos et al., 2012).

Homeopathic medicines can be used in the treatment and prevention of acute, chronic and epidemic disorders. They can decrease individual susceptibility predisposing to diseases, instead of attacking the causative agent of the disorder, activating the healing forces of the organism itself, through stimulating the immune system, restoring the homeostasis and the health of the individual (Grams, 2019; Teixeira, 2013). The success of any homeopathic treatment is directly related to the correct choice of the medication to be used. According to Hahnemann (1995), the totality of symptoms that are repeated in a greater number of affected individuals, in an epidemic, is called "Epidemic Genius". In the homeopathic treatment of epidemic diseases, knowledge of the Epidemic Genius is essential for choosing the most appropriate remedy (Hahnemann, 1995).

The application of homeopathy in animal production is less aggressive and more sustainable, based on animal welfare (Casali et al., 2013). Its use in the control of ticks has been the objective of several studies (Braccini et al., 2019; Gemelli and Pereira (2018). It is considered safe because it does not leave residues and does not produce contamination, reducing the applications of synthetic ticks, delaying resistance. It can interfere with the tick life cycle by reducing the number of teleogins, oviposition and hatching (Braccini et al., 2019; Gemelli and Pereira, 2018). Even so, before this research, no field work was able to prove the efficiency of homeopathy in controlling the parasitism of dairy cattle by ticks, perhaps due to the lack of a methodology, proven 
effective and scientifically validated, suitable for the choice of the medicine.

The objective of this research was to compare the use of organosynthetics (Clorfenvinfós and Ivermectina), phytotherapics (Neem and Eucalyptus) and homeopathic preparations to control parasitism by $R$. microplus and weight gain in dairy cattle, in field tests, in the South region Fluminense, State of Rio de Janeiro, Brazil. For the assessment of homeopathy, a new methodology was developed and tested for choosing homeopathic medicines for the control of enzooties.

\section{MATERIAL AND METHODS}

The field tests were carried out at the Experimental Field of Santa Mônica (CESM), of Embrapa Gado de Leite, located in the Municipality of Valença-RJ, at $446 \mathrm{~m}$ of altitude, in the geographical coordinates $22^{\circ} 21^{\prime}$ of South Latitude and $43^{\circ} 42^{\prime}$ West Longitude of Greenwich. The climate of this region is characterized as tropical in altitude, with an average annual temperature of $21.3{ }^{\circ} \mathrm{C}$ and an average annual rainfall of $1411 \mathrm{~mm}$. The other stages were carried out at the Parasitology Laboratory of Embrapa Gado de Leite (Embrapa), in Juiz de Fora, MG and at the Federal Rural University of Rio de Janeiro (UFRRJ), in Seropédica-RJ.

Sixty male and female bovines participated in the experiments, in good health, with blood level from $3 / 4$ Dutch / Zebu, aged between 25-44 months and initial weight between $211-477 \mathrm{~kg}$. The animals were kept in 5 paddocks of approximately 9.0 ha each, with Brachiaria decumbens grass, naturally infested by $R$. microplus, for 30 months.

The animals were homogeneously distributed among the five experimental groups, considering blood degree, weight, age and degree of infestation, determined by counting the total number of ticks on the left side of each animal's body in the previous three days to treatment (-3, 2 and -1). Weekly tick counts were made from $4.5 \mathrm{~mm}$ in length until they had at least 20 ticks on each animal on day -1 . Then, the five animals, with the highest average tick count, were randomly allocated, one in each group, and so on, until the five groups were completed with twelve animals each. In this way, the groups started the test with a remarkably similar average number of ticks (Wharton and Utech, 1970).

The research project was approved by the Ethics Committee on the Use of Animals, CEUA / IV / UFRRJ, under number 3290230915.

The "double blind" procedure was adopted, that is, the applicators and the evaluators did not know which product was being applied to each group of animals. All groups received water and mineral salt ad libitum. During the dry season, $1 \mathrm{~kg}$ of feed / animal / day was supplemented.

The five groups, being 4 treatments and 1 control, were named as follows: Organosynthetic Chemical Group (OG); Eucalyptus Group (EG); Neem Group (NG); Homeopathy Group (HG) and Control Group (CG).

Chemical group (OG) - Sensitivity tests were carried out, according to Drummond et al. (1973), at Embrapa's Parasitology Laboratory, in order to choose the products that proved to be the most effective in controlling the tick population of CESM.

In this case, the products chosen were: Supokill@, from the UCBVET Saúde Animal Laboratory (active ingredient Clorfenvinfós) which had the previous name of "Carrapaticida e Sarnicida UCB ${ }^{\circledR}$ " and Ivomec ${ }^{\circledR}$, from the Merial Saúde Animal laboratory (active ingredient Ivermectina).

The applications took place based on the methodology described for the Strategic Tick Control according to Furlong et al. (2003). The first five applications took place every 21 days, between January and April (middle and end of the rainy season) using top ticks Supokill@.

Each animal was "sprayed" by costal sprayer, with 4 to 5 liters of syrup, in the commercial dilution, following the recommendations recommended by Furlong (2001).

In September (end of the dry season) parasiticide Ivomec $\AA$ was applied, subcutaneously, at a concentration of $200 \mu \mathrm{g} / \mathrm{kg}$, as recommended by the manufacturer. The animals in this group received, ad libitum, throughout the experimental period, a mixture of crystal sugar and mineral salt, in the proportion of $500 \mathrm{~g} / 25 \mathrm{~kg}$. 
Eucalyptus Group (EG) - Each animal received five "sprays" by costal sprayer, with 4 to 5 liters of $15 \%$ syrup (E. globulus essential oil from the SYNTH® brand), as recommended by the manufacturer, every 21 days, from January to April, following the recommendations recommended by Furlong (2001). The animals in this group received, ad libitum, throughout the experimental period, a mixture of crystal sugar and mineral salt, in the proportion of $500 \mathrm{~g} / 25 \mathrm{~kg}$.

Neem Group (NG) - This group was made available, ad libitum, throughout the experimental period, the mixture containing $2.5 \mathrm{~kg}$ of mineral salt (previously mixed with crystal sugar in the proportion of $500 \mathrm{~g} / 25 \mathrm{~kg}$ ) and $80 \mathrm{~g}$ of Neem cake, as recommended by the manufacturer.

Homeopathy Group (HG) - In this group the animals received, ad libitum, throughout the experimental period, a mixture of $500 \mathrm{~g}$ of the homeopathic preparation and $25 \mathrm{~kg}$ of mineral salt. To determine the homeopathic preparation, a new methodology was developed, described later.

The choice of the homeopathic medicine was due to the adaptation of the methodology, recommended by Hahnemann (Hahnemann, 1995), for the treatment of epidemics in humans with homeopathy combined with the methodology of "population homeopathy", described by Real (2008). Due to the variability of the symptoms verified (Epidemic Genius), according to the books "Acologia Homeopática" (Casali et al., 2013) and "Homeopatia Tri-Una na
Agronomia" (Arruda et al., 2005), we opted for a homeopathic preparation composed of the Nux Vômica Complex, Sulfur and Staphisagria, plus the "Rhipicephalus Microplus" (It refers to the name of the medicine and not the name of the arthropod. In this case, italics will not be used. Nosode (Nosode is the homeopathic medicine prepared from the disease-causing agent itself (Arruda et al., 2005), all in the 12th dynamization (Hahnemann, 1995).

The set of symptoms (Epidemic Genius) according to the methodology formulated by Hahnemann, in cases of epidemics in humans (Hahnemann, 1995; Nunes, 2016; Teixeira, 2013) can be seen in the Table 1 .

Table 1. Symptoms presented by the population of animals infested by Rhipicephalus microplus and which define the Epidemic Genius of enzooty for the purpose of this study

Epidemic genius of the enzootic disease

\begin{tabular}{lc}
\hline & Symptoms \\
Loss of appetite & Blood loss \\
uneasiness & Anxiety \\
Itching & Weakness \\
Excoriation in leather & Ectoparasitosis \\
Anemia & Wounds \\
Inflammation & It does not stop scratching \\
\hline
\end{tabular}

Table 2 contains the drugs that, according to Homeopathic Acology, presented similar symptoms (Medicinal Genius) to the Epidemic Genius of the enzooty studied (Arruda et al., 2005; Casali et al., 2013).

Table 2. Homeopathic medicines and their respective symptoms (Medicinal Genius), similar to the Epidemic Genius found in the enzooty of the studied population, according to homeopathic acology (Arruda et al., 2005; Casali et al., 2013). CH12 dynamization was chosen according to Romanach (1984)

\begin{tabular}{cccc} 
& & Homeopathic medicines & \\
& Nux Vômica & Staphysagria & Sulphur \\
\hline $\mathrm{S}$ & Loss of appetite & Lice herb & Itchy \\
$\mathrm{Y}$ & Increased excitation & Skin lesions & Eczema \\
$\mathrm{M}$ & Increased irritability & Wounds & Sick skin \\
$\mathrm{P}$ & Fatigue & Dermatoses & Itching until it is raw \\
$\mathrm{T}$ & Anguish & Stress & Psoriasis \\
$\mathrm{O}$ & Hypersensitivity & Irritability & Itchy \\
$\mathrm{M}$ & & Loss of blood & \\
$\mathrm{S}$ & & Damaged fabrics & \\
& & Itchy skin & \\
\hline
\end{tabular}

The "Rhipicephalus Microplus" nosode was selected with the objective of increasing the body's energy (vital force), stimulating and restoring the energy flow, restoring the dynamic balance of the treated animals (Arruda et al., 2005). 
Thus, the drugs Nux vomica CH12, Staphysagria $\mathrm{CH} 12$ and Sulfur $\mathrm{CH} 12$ were selected for the composition of a homeopathic complex that, added to the "Rhipicephalus Microplus" nosode $\mathrm{CH} 12$, formed a unique medicine (Homeopathic preparation). The homeopathic complex Nux vomica, Staphysagria and Sulfur, were purchased in a homeopathic pharmacy.

The "Rhipicephalus Microplus" nosode was manipulated from Rhipicephalus microplus ticks, collected randomly from CESM's own tick population and which was parasitizing the bovines participating in the field test (Arruda et al., 2005).

The doses of the homeopathic complex $(3 \mathrm{~mL})$ and the nosode $(3 \mathrm{~mL})$ were added to $500 \mathrm{~g}$ of crystal sugar, in a glass bowl, mixed vigorously, with wooden spoon, until the mixture was shiny and totally loose from the bottom of the bowl. bowl, subsequently packed in translucent plastic bags and stored in a styrofoam box.

The homeopathic preparation was mixed with mineral salt, in the proportion of $500 \mathrm{~g} / 20 \mathrm{~kg}$, on the day of supply to the animals, being distributed in the paddock salt pan. As the "Double blind" procedure was adopted, the attendant did not know that the mineral salt was added to the homeopathic medicine.

Control Group (CG) - The animals in this group did not receive any treatment, receiving only water and mineral salt ad libitum, previously mixed with crystal sugar in the proportion of $500 \mathrm{~g} / 25 \mathrm{~kg}$, for comparison with the other groups.

The parameters evaluated in the research were: degree of infestation, given by the number of $R$. microplus females, and the weight gain by the animals. The degree of infestation was obtained by counting the engorged females of $R$. microplus that had a minimum size starting at $4.5 \mathrm{~mm}$, on the left side of the animals' body (Wharton and Utech, 1970). At the end of the experiment, the average ticks / group were calculated (Average Tick Infestation - MIC). Tick counts occurred every 21 days, totaling 34 collections.

The weighing of the animals occurred every 90 days, totaling 11 weightings. Weight gain was determined by the difference between the animals' weight at the beginning (animals entering the experiment) and at the end of the experiment (last weighing of the animals in the experiment). Average weight gain / group (GP) was calculated, decreasing the final weight of the initial weight and dividing the result by the number of animals in each group.

Initially, an exploratory analysis of the data of all groups was carried out, in order to observe the behavior of the infestation (MIC) and weight gain (GP) data (Bussad and Morettin, 2017). As a measure of dispersion, the coefficient of variation (CV) was calculated to assess the variability of the MIC and the GP, in general and in each group individually. Boxplots and violin plots were also used to verify data distribution. Longitudinal graphs were used to verify the distribution of infestation and weight gain over the experimental period (Hintze and Ray, 1998; McGill et al., 1978).

The Shapiro-Wilk tests (Conover, 1980), the Kruskal-Wallis non-parametric test (Kruskal and Wallis, 1952) and the Dunn post-test (Dunn, 1964) were applied, in order to verify the normality in data distribution and the existence of significant differences between treatments, respectively. For infestation data, logarithmic transformation, $\log (\mathrm{x}+1)$ was used. All analyzes were performed using the statistical package $\mathrm{R}(\mathrm{R}$ Core..., 2018).

\section{RESULTS AND DISCUSSION}

The exploratory analysis of the tick infestation data (MIC), of each group, as well as the animals as a whole are presented in Table 3. The eucalyptus group showed a significantly higher level of parasitism than the others (18.66 ticks), while in the homeopathy (8.03 ticks) and organosynthetic (8.38 ticks) groups the lowest infestation averages were observed.

Table 3 shows a greater infestation in the groups represented by the herbal medicines Eucalyptus oil (MIC $=18.66)$ and Neem cake (MIC $=11.52)$, which were above the averages of the other groups throughout the experimental period (Fig.1). Contrary to what was expected in this field study, E. globulus essential oil (EO) (SYNTH®), diluted to $15 \%$, as indicated by the manufacturer, did not control the infestation, presenting an $84.9 \%$ higher MIC $(\mathrm{P}<0.05)$ than the Control group $(\mathrm{MIC}=10.09)($ Table 3$)$. 
Table 3. Exploratory analysis of infestation data (MIC) of dairy cattle by Rhipicephalus microplus after treatment with organosynthetic parasiticides (topical Clorfenvinfós and injectable Ivermectin-GC), herbal medicines (Topical Eucalyptus globulus oil - GE and Neem cake - GN), homeopathic preparation (GH) and Control Group (GC) in field test. The data of the experiment as a whole (Total) are presented in minimum (MI), average (AV), median (MED), maximum (MA) and by the coefficient of variation (CV)

\begin{tabular}{lccccc}
\multicolumn{1}{c}{ Treatment } & MI & AV & MED & MA & CV $(\%)$ \\
\hline Total & 0 & 11.51 & 6 & 140 & 130.59 \\
CG & 0 & $10.09^{\mathrm{b}}$ & 5 & 62 & 106.46 \\
EG & 0 & $18.66^{\mathrm{a}}$ & 12 & 140 & 118.94 \\
HG & 0 & $8.03^{\mathrm{c}}$ & 5 & 62 & 119.98 \\
NG & 0 & $11.52^{\mathrm{b}}$ & 6 & 110 & 119.30 \\
OG & 0 & $8.38^{\mathrm{c}}$ & 5 & 98 & 135.19 \\
\hline
\end{tabular}

Average values with a different letter in the same column show a significant difference at $5 \%$ significance $(\mathrm{P}<0.05)$ by the Kruskal-Wallis non-parametric test.

Fig.1 shows the longitudinal distribution of infestation (MIC) of the animals throughout the experimental period. As can be seen from the analysis of the figure, the eucalyptus group showed levels of parasitism higher than the others during the entire experimental period. Intermediate levels were observed in the CG and NG groups, while the HG and OG treatments demonstrated greater activity in reducing parasitism throughout the experiment.

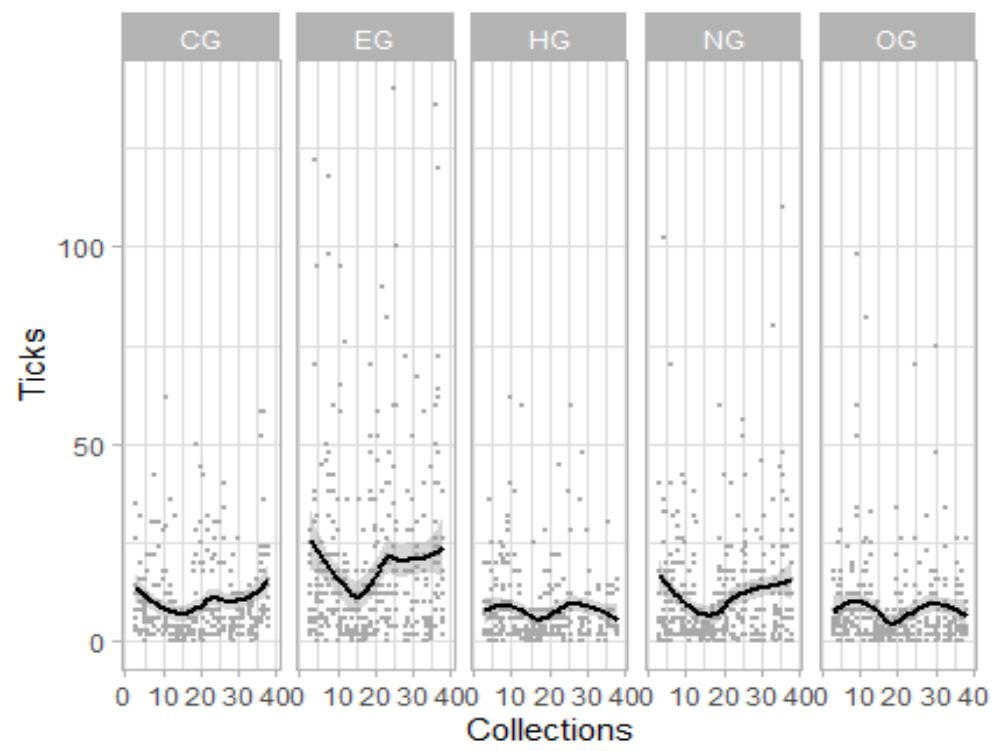

Figure 1. Longitudinal distribution of the Infestation (MIC), by Rhipicephalus microplus, over the experimental period, after treatment with organosynthetic parasiticides (topical Clorfenvinfós and injectable Ivermectin- OG), herbal medicines (topical Eucalyptus globulus essential oil - EG and Neem cake - NG), homeopathic preparation (HG) and control group (No parasiticidal treatments - CG). The curve in each treatment shows the evolution of the average infestation over the field test period.

It is noted that the form of use (presentation) and the concentrations used directly interfere in the efficacy of E. globulus, since the ethanol extract of Eucalyptus sp. showed $97.45 \%$ efficacy over $R$. microplus in a study by Alves et al. (2014). Olivo
In in vitro tests, however, Galli et al. (2018), using essential oil of E. globulus, in concentrations of 5 and $10 \%$, demonstrated an efficiency of 85 and $97.8 \%$, respectively over $R$. microplus. These same authors, in an in vivo test using EO of $E$. globulus in nanoemulsions and nanocapsules (5\%), demonstrated an efficiency of $61.2 \%$ and $50 \%$, respectively. 
Although Santos et al. (2017) considered that products based on Neem may represent an alternative to the use of organosynthetics, in the present work this was not observed. In the group treated with Neem cake there was also no infestation control, presenting a MIC $14.0 \%$ higher than the control group $(\mathrm{P}<0.05)$ (Table 3$)$. Costa et al. (2008) reported that the hydroalcoholic extract of Neem, at a concentration of $20 \%$, demonstrated a tick-like efficacy of $32 \%$ in vitro, which is considered a low efficacy according to the parameters of the Ministry of Agriculture, Livestock and Supply of Brazil (Effectiveness $\geq$ 90\%) (Brazil, 1990), however, Valente et al. (2007), in an in vivo study, found that there was no difference in infestation when comparing the effectiveness of the aqueous extract of fresh leaves of Neem $(1 \mathrm{~kg}$ of fresh leaves in 5 liters of water) with abamectin. In another in vivo study, using Neem cake, supplied daily to animals, and Neem oil in strategic treatments, Catto et al. (2013) did not find significant effects on $R$. microplus infestation. No more recent in vivo studies were found in the literature on the effects of the Neem cake on infestation by $R$. microplus.

Through the graphs in the form of violin (Fig.2) it is possible to observe, simultaneously, the frequency and the distribution of the data dispersion, referring to the infestation transformed in logarithm in each treatment. The Violin Plots centerline indicates the confidence interval $(\mathrm{CI}=95 \%)$.

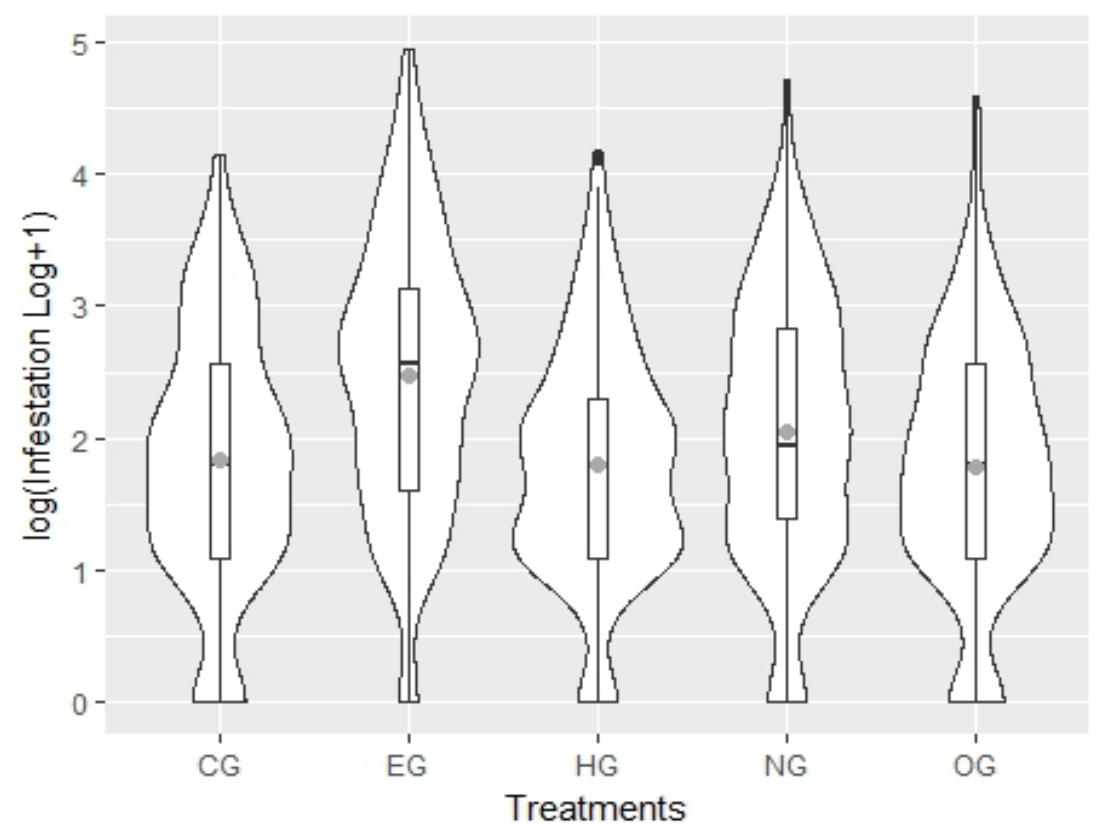

Figure 2. Exploratory analysis and distribution of data dispersion, related to animal infestation (MIC), by Rhipicephalus microplus, after treatment with organosynthetic parasiticides (topical Clorfenvinfós and injectable Ivermectin- OG), herbal medicines (topical Eucalyptus globulus essential oil - EG and Neem cake - NG), homeopathic preparation (HG) and control group (Without parasiticidal treatments- CG), in field tests, transformed by the Logarithmic function $\log (x+1)$.

In the group treated with Homeopathic preparation, the infestation was $20.4 \%$ lower than in the control group (MIC $=8.03$ and 10.09, respectively) $(\mathrm{P}<0.05)$. In Fig. 1 it can be seen that the longitudinal distribution of the data, in the homeopathy group, forms a more harmonious line and lower than the other groups throughout the experimental period, showing little variation and, when this variation happens, the line becomes shifts downward, indicating a drop in the MIC.
The same record is seen in Fig.2, where most of the data mass (MIC) is located up to the second quartile and is distributed around the mean and median, indicating greater homogeneity in the distribution of the data mass dispersion.

Corroborating these results, Silva et al. (2008) comparing Biotherapy (Arenales Fauna \& Flora CH12) with a control group, reported a $50.5 \%$ reduction in the number of engorged females; 
Signoretti et al. (2013) reported a 90\% reduction in the use of ticks in a group of calves treated with homeopathy compared to an untreated group. However, Figueiredo et al. (2018) using a 30CH biotherapeutic did not find significant differences in infestation in relation to the control group. Valente et al. (2017) also reported very low effectiveness $(42 \%)$ of a $6 \mathrm{CH}$ biotherapeutic formulation.

This difference in results may be related to the difference in methodology applied to the choice of homeopathic medicine. However, none of these authors reported the methodology used to choose the homeopathic medication and this is a fundamental point in the treatment of any imbalance or disorder with these medications (Hahnemann, 1995).

Disregarding the symptoms of the disease, in the case of homeopathy treatments, makes the choice of the medication devoid of technical, scientific and methodological grounds. The new methodology for the use of homeopathic preparations in the control of enzooties, developed and tested for the first time in this study, demonstrated excellent results, which can be adopted in future field studies.
The Organosynthetic group $(\mathrm{MIC}=8.38)$ also demonstrated to be able to control the infestation. When compared to the control group (MIC = 10.09), a statistically significant reduction $(\mathrm{P}<0.05)$ of $16.9 \%$ was observed (Tab.3). There was no significant difference in relation to the group treated with homeopathy $(\mathrm{MIC}=8.03)(\mathrm{P}=$ 0.4877) (Table 3; Fig.1). Fig.2 shows that in the Organosynthetic group there was less homogeneity in the distribution of the dispersion of the data mass.

These results indicate that Homeopathy can be used to control $R$. microplus, replacing organosynthetics, considering the new methodology for choosing and using homeopathic medicines to control enzooties, presented and validated in this study.

The averages of weight gain (GP) of the groups separately and of the animals as a whole, are shown in Table 4. It can be seen that the groups had very similar mean weights (PI) at the beginning of the research, with no statistical differences between them $(\mathrm{P}=0)$, showing homogeneity between the groups (Table 4).

Table 4. Exploratory analysis of data, weight gain (GP) in $\mathrm{kg}$, by dairy cattle, after treatment with organosynthetic parasiticides (topical Clorfenvinfós and injectable Ivermectin - OG), herbal medicines (Topical Eucalyptus globulus essential oil - EG and Neem cake- NG), homeopathic preparation (HG) and the control group (without parasiticidal treatment- $\mathrm{CG}$ ) in field test. The data show average starting weight (IW); minimum weight (MI); averages (AV); medians (MED); maximum weight (MA) and coefficient of variation $(\mathrm{CV})$

\begin{tabular}{lcccccc}
\hline \multicolumn{1}{c}{ Treatment } & IW & MI & AV & MED & MA & CV $(\%)$ \\
\hline Total & & 60 & 231.81 & 234 & 443 & 31.73 \\
CG & $287^{\mathrm{a}}$ & 131 & $241.91^{\mathrm{b}}$ & 230 & 414 & 38.38 \\
EG & $299^{\mathrm{a}}$ & 60 & $222.70^{\mathrm{c}}$ & 235 & 290 & 22.31 \\
HG & $296^{\mathrm{a}}$ & 91 & $253.68^{\mathrm{a}}$ & 269 & 348 & 26.69 \\
NG & $286^{\mathrm{a}}$ & 119 & $220.39^{\mathrm{c}}$ & 221 & 313 & 25.60 \\
OG & $283^{\mathrm{a}}$ & 105 & $223.86^{\mathrm{c}}$ & 227 & 443 & 9.37 \\
\hline
\end{tabular}

Average values with a different letter in the same column show a significant difference among each other at 5\% significance $(\mathrm{P}<0.05)$ by the Kruskal-Wallis non-parametric test.

The longitudinal distribution of weight gain (GP) of the animals throughout the experimental period can be seen in the Fig.3. It is clear that the highlighted and growing increase in weight gain of the homeopathy group is evident over the experimental period in relation to the other groups, corroborating the statistical analysis presented in table 4. 

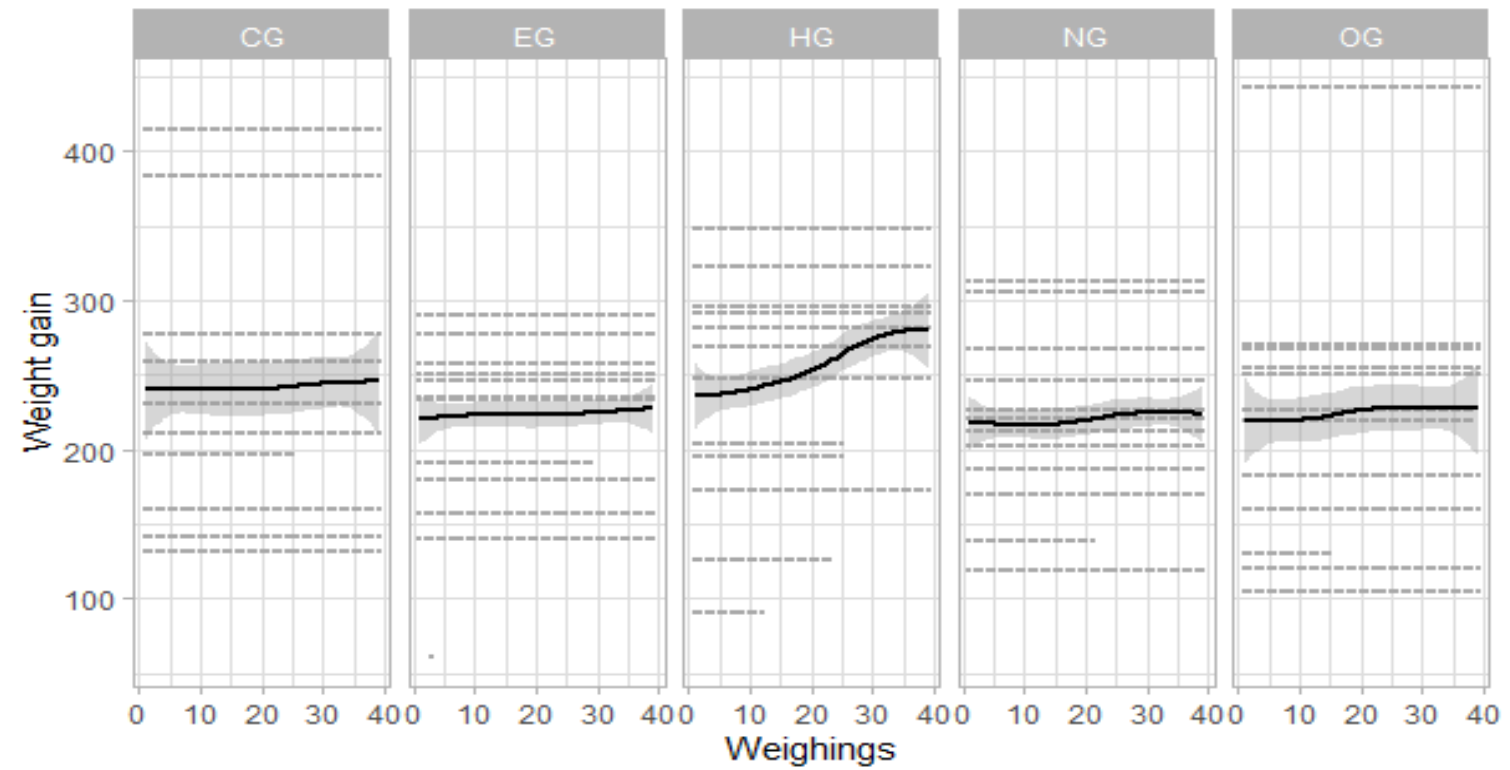

Figure 3. Longitudinal distribution of the animals' weight gain (GP), over the experimental period, after treatment with organosynthetic parasiticides (topical Clorfenvinfós and injectable Ivermectin - OG), phytotherapics (topical Eucalyptus globulus essential oil - EG and Neem cake - NG), homeopathic preparation (HG) and control group (No parasiticidal treatments - CG) in field test. The curve in each treatment shows the evolution of the average weight over the period of the experiment.

Through the violin-shaped graphs (Fig.4), it is possible to observe, simultaneously, the frequency and distribution of the weight gain data (GP) dispersion in each treatment. The Violin Plots centerline indicates the confidence interval $(\mathrm{CI}=95 \%)$.

It can be seen in Table 4 that the weight gain (GP) of the Neem group $(\mathrm{GP}=220.39 \mathrm{~kg}$ ) was the lowest among the groups, being statistically ( $\mathrm{P}$ $<0.05)$ less $(8.9 \%)$ than the Control group (GP = $241.91 \mathrm{~kg}$ ), but there was no statistical difference $(\mathrm{P}=0)$ when compared with the organosynthetic groups $(\mathrm{GP}=223.86 \mathrm{~kg})$ and Eucalyptus $(\mathrm{GP}=$ $222.70 \mathrm{~kg})$.

Catto et al. (2013), in an in vivo study, on the control of endo and ectoparasites in cattle, using Neem cake and strategic spraying with Neem oil, did not verify statistical difference $(P=0)$ in the weight gain of the group treated with the products Neem base, when compared to the untreated group.

The fact that the groups treated with herbal products used in this study showed less weight gain than the group without treatments, may have been a consequence of the greater infestation by $R$. microplus, in these groups, since neither the Neem cake nor the oil essential oil used in this study, were able to control the infestation (Tab.3). This fact further suggests the need for further studies with the aim of verifying possible intoxications and negative effects of phytotherapeutic and organosynthetic parasiticides on the physiological yield and production in dairy cattle, especially when it comes to products with systemic action on the animal. 


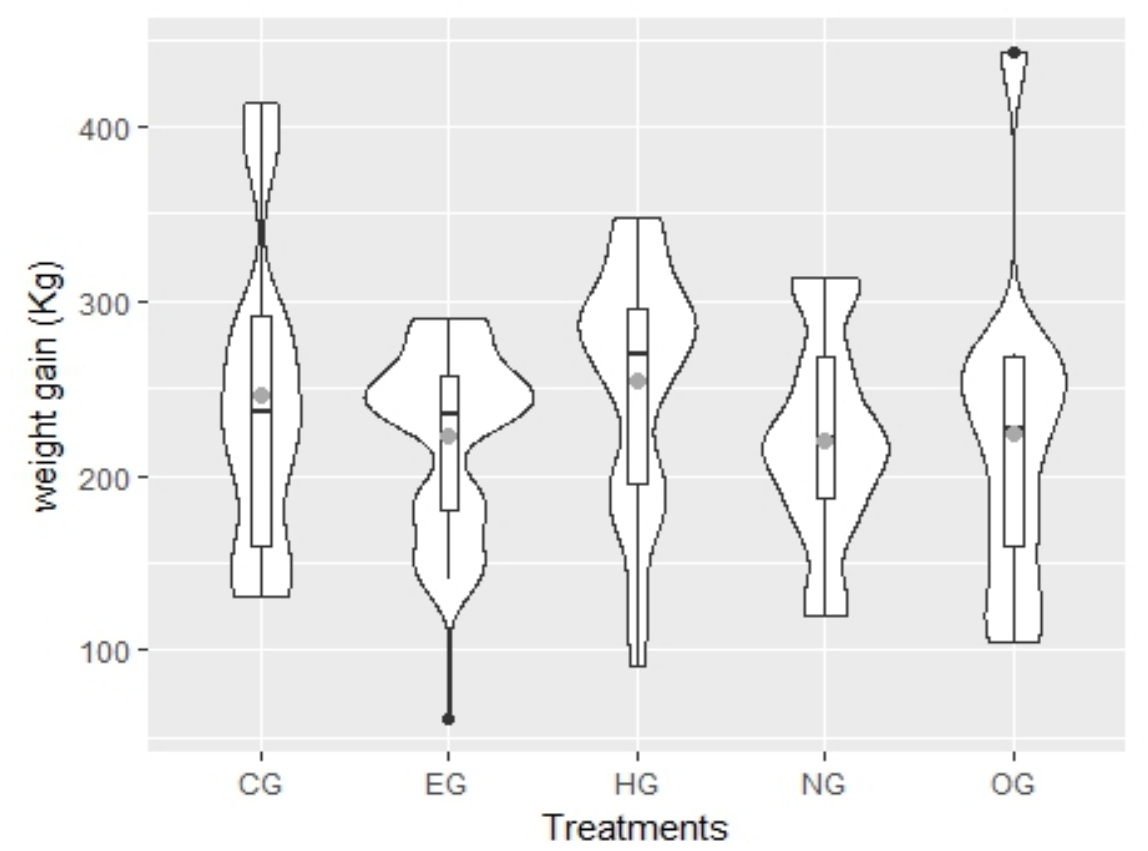

Figure 4. Graphical representation of the exploratory analysis and distribution of data dispersion, related to weight gain (GP), in $\mathrm{kg}$, by dairy cattle after treatment with organosynthetic parasiticides (topical Clorfenvinfós and injectable Ivermectin - OG), herbal medicines (essential oil of Topical Eucalyptus globulus - EG and Neem cake- NG), homeopathic preparation (HG) and the control group (without parasiticide - CG treatment) in field test.

Weight gain in the Eucalyptus group $(\mathrm{GP}=222.70)$ was statistically lower $(\mathrm{P}<0.05)$ than in the Control group $(\mathrm{GP}=241.91 \mathrm{~kg})$, that is, $7.9 \%$ less, but it was similar to the group organosynthetic $(\mathrm{GP}=223.86 \mathrm{~kg})$ $(\mathrm{P}=0)$.

The average weight gain (GP) in the group treated with organosynthetics $(\mathrm{GP}=223.86 \mathrm{~kg})$ was also $8.06 \%$ lower $(\mathrm{P}<0.05)$ than in the control group $(\mathrm{GP}=241.91 \mathrm{~kg}) \quad($ Table 4$)$. These results reinforce the opinions of Rodriguez-Vivas et al. (2018) and Santos et al. (2014), who considered compromised the use of organosynthetic parasiticides in the control of $R$. microplus, due to cases of animal poisoning, environmental contamination and products of animal origin, in addition to the proven resistance to most of the available chemical bases. Still according to Santos et al. (2014), cases of animal poisoning by organosynthetic products in Brazil are not uncommon. These authors reported cases that occurred in the states of Santa Catarina, Pará, Distrito Federal and Rio Grande do Sul, in which the animals died.

The group treated with the homeopathic preparation gained weight throughout the experimental period (Fig.3) $(\mathrm{GP}=253.68 \mathrm{Kg})$ surpassing all groups in this parameter $(\mathrm{P}<0.05)$, being $13.5 \%$ greater than the GP of the organosynthetic group (223.86kg) and $4.9 \%$ greater than the GP of the control group (GP = $241.91 \mathrm{~kg}$ ) (Table 4). These results are consistent with the therapeutic approach of homeopathy, which aims to stimulate the organism to react against its own disorders, awakening effective responses of homeostasis, provided that the drugs are correctly chosen, according to their similarity with the set of characteristic symptoms of patients (Teixeira, 2013), according to the homeopathic medicine choice methodology developed for this study.

In a stable test, Signoretti et al. (2010) observed weight gain in crossbred dairy cows that received commercial homeopathic products, daily in the concentrate for nine months, without the need to use allopathic products during this period. In another study, however, Signoretti et al. (2013) evaluating the body development of dairy calves, from 0 to 120 days of age, who received a diet with or without the use of a commercial 
homeopathic medicine, did not observe any significant influence on the animals' body development when they added homeopathy to the diet. Figueiredo et al. (2018), in a stable test, evaluated the effectiveness of the homeopathic biotherapeutic preparation $30 \mathrm{CH}+$ Sulfur $30 \mathrm{CH}$, in the control of ticks in taurine dairy cows for 12 months. and there were no statistical differences in body weight of treated and untreated animals. However, the difference in these results cannot be justified because the authors did not inform the methodology used for the choice of homeopathic medicines. The success of homeopathic treatment is directly related to the correct choice of medication (Hahnemann, 1995).

The statistical similarity between the infestation found between the homeopathy and organosynthetic groups, in addition to the statistically superior weight gain in the homeopathy group in the face of allopathic treatments, allows us to state that the homeopathic preparation Nux Vômica CH12, Sulfur CH12 and Staphisagria CH12 + Rhipicephalus Microplus $\mathrm{CH} 12$ can be considered in studies aimed at establishing a new methodology for strategic parasitism control programs by $R$. microplus in dairy cattle. However, new studies are suggested that assess the reproductive biology of the collected ticks and the economic parameters of this treatment, among others.

This new methodology must be tested / used in new research from now on. In confirming the good results achieved, it will be possible to establish a methodology for choosing the medicine to control the tick of cattle using homeopathic medicines.

\section{CONCLUSIONS}

This is the first field study to demonstrate the increase weight gain and reduced level parasitism by $R$. microplus in cattle using homeopathic medicine. This success may be related to the new methodology for choosing the homeopathic medicine used, developed and tested for the first time in the present study. This was the first scientific research to adapt and test the methodology of choosing homeopathy to combat human epidemics, established by Hahnemann, combining it with population homeopathy to choose the homeopathic medicine aiming at the control of enzooties.

\section{ACKNOWLEDGMENTS}

We would like to thank the National Council for Scientific and Technological Development CNPq, the Minas Gerais State Research Support Foundation - FAPEMIG for the financial support for research work, and the Higher Education Personnel Improvement Program (CAPES), Brazilian Company Agricultural Research Institute - EMBRAPA, Carlos Chagas Filho de Amparo Research Foundation of the State of Rio de Janeiro (FAPERJ) and the Federal Institute of Southeast Minas Gerais, for the financial contribution.

\section{REFERENCES}

ALMEIDA, L.R. Manejo de parasitoses em sistema orgânico de produção de leite. Arq. Inst. Biol., v.80, p.129-134, 2013.

ALVES, R.H.; BATISTA, I.L.; SILVA, K.K. et al. Efeito do extrato etanólico de Eucalyptus sp. sobre fêmeas ingurgitadas e larvas de Rhipicephalus (Boophilus) microplus. Bol. Inf. Geum, v.5, p.113, 2014.

ARRUDA, V.M.; LISBOA, S.P.; CUPERTINO, M.C. Homeopatia Tri-Una na agronomia. Viçosa, Brasil, 2005. 119p.

BRACCINI, G.L.; SILVA, S.C.C.; CARNIATTO, C.H.O. et al. Aplicação da homeopatia na produção animal. Rev. Valore, v.4, p.310-323, 2019.

BRASIL, Ministério da Agricultura Pecuária e Abastecimento. Portaria n. 90 de 04 de dezembro de 1989. Normas para produção, controle e utilização de produtos antiparasitários, Edição de Brasília, DF, Brasil, 1990.

BUSSAD, W.O.; MORETTIN, P.A. Estatística básica. 9.ed. São Paulo: Saraiva, 2017. 568p.

CAMPOS, R.N.; BACCI, L.; ARAÚJO, A.P.A. et al. Óleos essenciais de plantas medicinais e aromáticas no controle do carrapato Rhipicephalus microplus. Arch. Zootec., v.61, p.67-78, 2012.

CASALI, V.W.D.; ANDRADE, F.M.C.; PAIXÃO, J.L.F. et al. Acologia homeopática e disfunções vitais. Viçosa: UFV, 2013. 191p. 
CATTO, J.B.; BIANCHIN, I.; FEIJÓ, G.L.D. et al. Weight gain and control of endo and ectoparasites of beef heifers treated with allopathic, herbal and homeopathic drugs. Rev. Bras. Parasitol. Vet., v.22, p.502-510, 2013.

CHARLIE-SILVA, I.; GIGLIOTI, R.; MAGALHÃES, P.M. et al. Lack of impact of dietary inclusion of dried Artemisia anпиа leaves for cattle on infestation by Rhipicephalus (Boophilus) microplus ticks. Ticks Tick-Borne Dis., v.9, p.1115-1119, 2018.

CONOVER, W.J. Practical nonparametric statistics. 2.ed. Minnesota: Wiley, 1980. 512p.

COSTA, F.B.; VASCONCELOS, P.S.S.; SILVA, A.M.M. et al. Eficácia de fitoterápicos em fêmeas ingurgitadas de Boophilus microplus, provenientes da mesorregião oeste do Maranhão, Brasil. Rev. Bras. Parasitol. Vet., v.17, p.83-86, 2008.

DANTAS-TORRES, F.; FERNANDES, M.T.; MUÑOZ-LEAL, S. et al. Ticks (Ixodida: Argasidae, Ixodidae) of Brazil: Updated species checklist and taxonomic keys. Ticks Tick-Borne Dis., v.10, 2019.

DRUMMOND, R.O.; ERNEST, S.E.; TREVINO, J.L. et al. Boophilus annulatus and B. microplus: laboratory tests of inseticides. J. Econ. Entomol., v.66, p.130, 1973 .

DUNN, O.J. Multiple comparisons using rank sums. Technometrics, v.6, p.241-252, 1964.

FIGUEIREDO, A.; FANTATTO, R.R.; AGNOLON, I.C. et al. In vivo study of a homeopathic medicine against Rhipicephalus (Boophilus) microplus in dairy cow. Rev. Bras. Farmacogn., v.28, p.207-213, 2018.

FURLONG, J. Controle de carrapato, berne e mosca dos chifres. Viçosa: CPT, 2001. 140p.

FURLONG, J.; MARTINS, J.R.S.; PRATA, M.C. Carrapato dos bovinos: controle estratégico nas diferentes regiões brasileiras. Juiz de Fora, MG: Embrapa, 2003. 6p. (Comunicado Técnico, n.36).

FURLONG, J.; SALES, R.O. Controle estratégico de carrapatos no bovino de leite: uma revisão. Rev. Bras. Hig. Sanidade Anim., v.1, p.44-72, 2007.
GALLI, G.M.; VOLPATO, V.; SANTOS, R.C.V. et al. Effects of essential oil of Eucalyptus globulus loaded in nanoemulsions and in nanocapsules on reproduction of cattle tick (Rhipicephalus microplus). Arch. Zootec., v.67, p.494-498, 2018.

GAZOLLA, M.; LOVATEL, M. Novidades construídas no sistema de produção do leite orgânico na região Extremo Oeste de Santa Catarina. Redes, v.25, p.1422-1446, 2020.

GRAMS, N. Homeopathy-where is the science? A current inventory on a pre-scientific artifact. $2019 . \quad$ Disponível em: https://www.embopress.org/doi/full/10.15252/em br.201947761. Acessado em: 26 fev. 2021.

GEMELLI, J.L.; PEREIRA, I.S.C. Principles and uses of homeopathy in beef cattle. A reviwue. Rev. Bras. Hig. Sanidade Anim., v.12, p.327-341, 2018.

GRISI, L.; LEITE, R.C.; MARTINS, J.R.S. et al. Reassessment of the potential economic impact of cattle parasites in Brazil. Rev. Bras. Parasitol. Vet., v.23, p.150-156, 2014.

HAHNEMANN, S. Organon da arte de curar. 2.ed. tradução da 6.ed. alemã. São Paulo: GEHSP "Bernoit Mure", 1995. 191p.

HINTZE, J.L.; RAY, D.N. Violin plots: a box plot-density trace synergism. Am. Stat., v.52, p.181-184, 1998.

KRUSKAL, W.H.; WALLIS, A. Use of ranks in one-criterion variance analysis. J. Am. Stat. Assoc., v.47, p.583-621, 1952.

MCGILL, R.; TUKEY, J.; LARSEN, W. Variations of box plots. Am Stat., v.32, p.12-16, 1978.

NAGAR, G.; SHARMA, A.K.; KUMAR, S. et al. Molecular mechanism of synthetic pyrethroid and organophosphate resistance in field isolates of Rhipicephalus microplus tick collected from a northern state of India. Exp. Appl. Acarol., v.75, p.319-331, 2018.

NUNES, L.S. Homeopathy and dengue: Macaé, Rio de Janeiro, Brazil, 2007-2012. Rev. Homeopatia, v.79, p.1-16, 2016.

OLIVO, C.J.; AGNOLIN, C.A.; PARRA, C.L.C. et al. Efeito do óleo de eucalipto (Corymbia citriodora) no controle do carrapato bovino. Ciênc. Rural, v.43, p.331-337, 2013. 
PAVELA, R.; CANALE, A.; MEHLHORN, H. et al. Application of ethnobotanical repellents and acaricides in prevention, control and management of livestock ticks: a review. Res. Vet. Sci., v.109, p.1-9, 2016.

PAZINATO, R.; VOLPATO, A.; BALDISSERA, M.D. et al. In vitro effect of seven essential oils on the reproduction of the cattle tick Rhipicephalus microplus. J. Adv. Res., v.7, p.1029-1034, 2016.

$\mathrm{R}$ CORE Team. R, a language and environment for statistical computing. R Found. Stat. Comput, 2018. Available in: https://www.R-project.org. Accessed in Feb. 08th, 2021.

REAL, C.M. Homeopatia populacional fundamentos ruptura de um paradigma. A hora da Veterinária, 2008. Available in: https://silo.tips/download/homeopatiapopulacional-fundamentos-ruptura-de-umparadigma. Accessed in: Feb. 08th, 2020.

RODRIGUEZ-VIVAS, R.I.; JONSSON, N.N.; BHUSHAN, C. Strategies for the control of Rhipicephalus microplus ticks in a world of conventional acaricide and macrocyclic lactone resistance. Parasitol. Res., v.117, p.3-29, 2018.

ROMANACH, A.K. Homeopatia em 1000 conceitos. São Paulo: Elcid, 1984, 607p.

SANTOS, B.L.; MARCOLONGO-PEREIRA, C.; STIGGER, A.L. et al. Uso inadequado de organofosforados: Uma prática de risco para bovinos no Sul do Rio Grande do Sul. Pesqui. Vet. Bras., v.34, p.655-658, 2014.

SANTOS, E.P.; MARCO, C.; SOUZA, R. et al. Carrapaticidal neem performance and intercropping management in tick control: a systematic review of the literature. Cad. Ciênc. Agr., v.9, p.79-91, 2017.
SIGNORETTI, R.D.; VERÍSSIMO, C.J.; SOUSA, F.H.M. et al. Aspectos produtivos e sanitários de vacas mestiças leiteiras tratadas com produtos homeopáticos. Arq. Inst. Biol., v.77, p.625-633, 2010.

SIGNORETTI, R.D.; VERISSIMO, C.J.; DIB, V. et al. Desempenho e aspectos sanitários de bezerras leiteiras que receberam dieta com ou sem medicamentos homeopáticos. Arq. Inst. Biol., v.80, p.387-392, 2013.

SILVA, N.L.; MOLETTA, J.L.; MINHO, A.P. et al. Use of biotherapic in the control of natural infestation by Boophilus microplus: pilot study. Int. J. High. Dilution Res., v.7, p.36-38, 2008.

SILVEIRA, W.H.; CARVALHO, G.D.; PECONICK, A.P. Medidas de controle do carrapato

Rhipicephalus microplus: uma breve revisão. Pubvet, v.8, p.1136-1282, 2014.

TEIXEIRA, M.Z. La evidencia científica del modelo epistemológico homeopático. Homeopatía Méx., v.82, p.5-20, 2013.

VALENTE, M.; BARRANCO, A.; SELLAIVEVILLAROEL, A.B. Eficácia do extrato aquoso de Azadiracta indica no controle de Boophilus microplus em bovino. Arq. Bras. Med. Vet. Zootec., v.59, p.1341-1343, 2007.

VALENTE, P.P.; MOREIRA, G.H.F.A.; SERAFINI, M.F. et al. In vivo efficacy of a biotherapic and eugenol formulation against Rhipicephalus microplus. Parasitol. Res., v.116, p.929-938, 2017.

WHARTON, R.H.; UTECH, K.B.W. The relation between engorgement and dropping of Boophilus microplus (Canestrini) (Ixodidae) to the assessment of tick numbers on cattle. J. Aust. Entomol. Soc., v.9, p.171-182, 1970. 